\title{
PERAN PERHIMPUNAN ALKHAIRAAT DALAM MEMPERKUAT MAZHAB SYAFI'I DI KOTA PALU
}

\author{
Mohammad, Gani Jumat, Muhammad Syarif Hasyim*
}

\begin{abstract}
Abstrack
Perhimpunan Alkhairaat is one of the largest religious organizations in Eastern Indonesia, this institution is consistent with education and da'wah as well as social activities. In its guidance to Muslims, much emphasis is placed on the practice of the Shafi'i School, and this is the will of the founder of this institution, Sayyid Idrus bin Salim Al Jufri. The research method in this article uses a qualitative approach, data collection techniques through observation, interviews and documentation, data analysis techniques used are data reduction, data presentation and data verification. The results of this study also show that the role of the Alkhairaat Association greatly contributes to the strengthening of the Syafi'i School in Palu City, through education in madrasas in this case the development of Islamic law. And in his own da'wah, Alkhairaat is consistent with fostering in the community through teachers who are also preachers with Alkhairaat Alumni backgrounds through ta'lim assemblies. In addition, the Alkhairaat Association also encountered obstacles in strengthening the Syafi'i School in Palu City, namely in the form of infrastructure and the increasingly widespread and large distribution of the Alkhairaat madrasa so that all preachers who were directly involved in the community could not cover it. It is recommended to all abnaulkhairaat to always pay attention to madrasas wherever they are. Because from this madrasa is the foundation in shaping Islamic character
\end{abstract} Keywords: “Alkhairaat; mazhab; Syafi'i; Guru Tua”

\section{A. PENDAhULUAN}

Masyarakat Indonesia yang mayoritas beragama Islam mengikuti mazhab Syafi'I yang di perkenalkan oleh pedagang dari Gujarat (India Selatan), Persia dan Arab, mereka inilah menjadikan cikal bakal tersebar luasnya mazhab ini di 
Indonesia. Mazhab Syafi'I semakin berkembang setelah kedatangan orang Arab yang berasal dari Negeri Hadramaut ${ }^{1}$ (Yaman), mereka datang bukan hanya sebagai pedagang tetapi juga mencari pekerjaan dan menyerukan dakwah islamiyah. ${ }^{2}$ Negeri Hadramaut(Yaman) sendiri merupakan Negeri yang di mana masyarakatnya penganut terbesar dari Mazhab Syafi'I bahkan dari negeri inilah lahir- Ulama-ulama yang mengarang kitab-kitab fiqih yang bersumber dari pendapat dan komentar Imam Syafi'i.

Mazhab Syafi'i berkembang di Indonesia khususnya Kota Palu tidak terlepas dari kontribusi sala satu Ulama yang berasal dari Negeri Hadramaut(Yaman) yang bernama asli Sayyid Idrus bin Salim Al Jufri yang silsilah keturunan bersambung lansung dengan Rasulullah SAW dari Fatimah dan Ali bin Abu Thalib. ${ }^{3}$ Sayyid Idrus bin Salim Al-jufri dalam melakukan pembinaan umat melalui sebuah lembaga yang ia dirikan dengan nama "Madrasah Alkhairaat Islamiyyah" yang kemudian berubah menjadi perguruaan Islam Alkhairaat. ${ }^{4}$

Melaului pendidikan dan dakwah Islam, Alkhairaat mendasari gerakanya kepada sumber pokok ajaran Islam yaitu Al Quran dan Sunnah. Di samping itu Alkhairaat menitikberatkan pada mazhab Syafi'l, sekalipun tidak menutup kemungkinanuntuk mengambil pendapat salah satu imam mazhab yang empat dan

\footnotetext{
${ }^{1}$ Hadramaut adalah merupakan salah satu provinsi di Negara Yaman Selatan (sebelum bersatu dengan Yaman Utara "Yaman Bersatu") yang terletak di lautan India, Arabia Selatan

${ }^{2}$ Ahmad Bachmid, Sang Bintang Dari Timur Sayyid Idrus Al-Jufri Sosok Ulama \& Sastrawan,( Jakarta: studia press, 2007), h. 2.

${ }^{3}$ Idrus bin Salim bin Alawi bin Saqqaf bin Muhammad bin Idrus bin Salim bin Husain bin Abdillah bin Syaikhan bin Alawi bin Abdillah at Tarisi bin Alawi bin Abi Bakar Al-Jufri bin Muhammad bin Ali bin Muhammad bin Ahmad bin Al Faqih al Muqaddam bin Muhammad bin Ali bin Muhammad Shahib Mairbath bin Ali Khali'Qasam bin Alawi bin Alawi bin Muhammad bi Alawi bin Ubaidillah bin al Muhajir lla Allah Ahmad bin Isa bin Muhammad bin Ali Uraidhi bin Jafar al Shadiq bin Muhammad al Baqir bin Ali Zain al'Abidin bin Al Husain bin Ali bin Abi Thalib dan Ibn Fathimah Az Zahra binti Rasulillah Saw. (Kitab Syajarah al Sadah al Alawiyyin, Makhthuth (Manuskrip) di simpan dalam perpustakaan Mufti Tarim, Jilid III, h. 97 - Abd. Rahman bin Muhammad al Masyhur, Syamsu al Zhahirah fi Ansabi al Sadah al Awaliyah (Jeddah: 'Alam al Ma'rifah, 1404 H/1984 M), Jilid II 410 'Alawi bin Saggaf bin Muhammad al Jufri, Syarh 'Umadatu al Salik wa 'uddah al Nasik (Tarim Hadhramaut: Dar al Mirats al Nabawi, 2011) di kutip dalam Huzaimah T. Yanggo, et. All.. Sayid Idrus Bin Salim Al Jufri Pendiri Alkhairaat Dan Kontribusinya Dalam Pembinaan Umat, ed.,: Abdul Wahab Abd.Muhaimin (Palu dan Jakarta : Yayasan Alkhairaat dan Gaung Persada (GP) Press), 9.

${ }^{4}$ Ahmad Bachmid, Sang Bintang Dari Timur Sayyid Idrus Al-Jufri Sosok Ulama \& Sastrawan,( jakarta: studia press, 2007), 23-24.
} 
para mujtahidin yang lain. Sehingga dapat dikatakan bahwa Alkhairaat sebagai gerakan yang memelihara dan memegang teguh ideologi Ahlu Al-Sunnah wa alJamaah dan bermazhab Syafi'i. ${ }^{5}$

Perhimpunan Alkhairaat dalam memelihara dan memegang teguh Mazhab Syafi'i adalah merupakan wasiat dari sang pendirinya yaitu Sayyid Idrus bin Salim Al Jufri Wasiat tersebut Dia tuangkan dalam gubahan syairnya mengenai kecintaanya terhadap mazhab Syafi'l

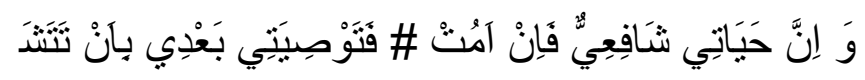

Sungguh amalia norma hidupku adalah mazhab Syafi'l, bila aku akan meninggal * maka aku berwasiat agar sesudahku nanti hendaklah kalian menjadikan mazhab Syafi'I sebagai panutan. ${ }^{6}$

Pada Muktamar X Alkhairaat juga menetapkan hasil keputusan yang tercantum dalam Anggaran Dasar (AD) Alkhairaat bab 2 tentang Asas dan Aqidah pasal 2 yaitu "perhimpunan ini berazaskan islam, berhaluan ahlusunnah wal jamaah berfaham asy'ariyah dan bermazhab syafi'i. ${ }^{7}$

Sayyid Idrus bin Salim Al Jufri dalam syairnya ini menyampaikan kepada penerusnya atau kepada para Abnaul khairaat ${ }^{8}$ untuk senantiasa menjadikan mazhab Syafi'i sebagai sebuah panutan sebagai landasan dalam syariat islam. Kemudian di kuatkan dalam Anggaran Dasar(AD)/Anggaran Rumah Tangga Perhimpunan Alkhairaat.

penulis menggunakan pendekatan kualitatif, yaitu penelitian yang digunakan untuk mendapatkan data yang mendalam, suatu data yang mengandung makna. Makna adalah data yang sebenarnya, data yang pasti yang merupakan suatu nilai

5 Huzaimah T. Yanggo, et. All.. Sayid Idrus Bin Salim Al Jufri Pendiri Alkhairaat Dan Kontribusinya Dalam Pembinaan Umat, ed.,: Abdul Wahab Abd.Muhaimin (Palu dan Jakarta : Yayasan Alkhairaat dan Gaung Persada (GP) Press), 2.

6 Abdullah Abdun,Sekelumit Tentang Perguruan Alkhairaat Dan Pendirinya,(malang:Daruttauhid 1996), 23-24.

7 Lihat Anggaran Dasar (AD)/Anggaran Rumah Tangga (ART) hasil Keputusan Muktamar X Alkhairaat Tahun 2014

8 Abnaul khairaat adalah orang-orang yang pernah belajar bersama pendiri Alkhairaat (Sayyid Idrus bin Salim Al Jufri) ataupun mereka yang perna belajar di sekolah atau madrasahmadarasah Alkhairaat (wawancara K.H Mansur A. Baba di Palu, 23 November 2020) 
dibalik data yang tampak. Oleh karena itu dalam penelitian kualitatif tidak menekankan pada generalisasi, tetapi lebih menekankan pada makna.

Pendekatan kualitatif dalam artikel ini karena fokus penelitian ini ialah untuk mengetahui secara jelas bagaimana Perhimpunan Alkhairaat dalam Memperkuat Mazhab Syafi'i Di Kota Palu

Berdasarkan sifat dan jenis permasalahannya, maka artikel ini merupakan rancangan studi deskriptif, yang bersusaha memberikan data secara sistematis dan cermat mengenai fakta-fakta aktual dan sifat populasi tertentu, terutama mengenai peran Perhimpunan Alkhairaat dalam Memperkuat Mazhab Syafi'i Di Kota Palu.

\section{B. PEMBAHASAN}

\section{Sejarah Singkat Perhimpunan Alkhairaat dan Pendirinya}

Perguruaan Islam Alkhairat yang sebelumnya bernama "Madrasah Alkhairaat Islamiyyah" didirikan pada tahun 1349 H/1930 M oleh Sayyid Idrus bin Salim Al Jufri (1309 H-1389 H/1890 M-1969 M), sala seorang ulama asal Hadharamaut Yaman Selatan (sebelum Yaman Utara "Yaman Bersatu"). Alkhairaat merupakan lembaga swasta yang sekaligus mitra Pemerintah yang bergerak di bidang pendidikan, dakwah dan sosial. Prinsip lembaga ini tidak berafiliasi pada kelompok tertantu, tapi landasanya bersifat agamis dan sasaranya adalah membangun watak manusia. ${ }^{9}$

Alkhairaat adalah lembaga pendidikan dan dakwah Islam, dalam dalam mendasari gerakanya kepada sumber pokok ajaran Islam yaitu Al Qur'an dan Sunnah. Di samping itu Alkhairaat menitikberatkan pada mazhab Syafi'l, sekalipun tidak menutup kemungkinanuntuk mengambil pendapat salah satu imam mazhab yang empat dan para mujtahidin yang lain. Sehingga dapat dikatakan bahwa Alkhairaat sebagai gerakan yang memelihara dan memegang teguh ideologi Ahli Al-Sunnah wa al-Jamaah dan bermazhab Syafi'i. di banding

\footnotetext{
${ }^{9}$ Sofjan B. Kambay, Perguruan Islam Alkhairaat Dari Masa Ke Masa,(Palu: 1991) 1; di kutib didalam Huzaimah T. Yanggo, et. All.. Sayid Idrus Bin Salim Al Jufri Pendiri Alkhairaat Dan Kontribusinya Dalam Pembinaan Umat, ed.,: Abdul Wahab Abd.Muhaimin (Palu dan Jakarta : Yayasan Alkhairaat dan Gaung Persada (GP) Press), 1.
} 
gerakan Islam lainnya, Alkhairaat tertanam kuat di Sulawesi Tengah, bukan hanya di daerah kota, bahkan di pelosok pedasaan pun dapat dijumpai lembaga pendidikan tersebut, hal inilah yang membedakan dengan lembaga-lembaga Islam lainnya seperti Nahdatul Ulama (NU), Muhammdiyah, Daru al Dakwah wa allrsyad dan lain sebagainya. ${ }^{10}$

Sayyid Idrus bin Salim Al-Jufri dilahirkan di Kota Taris, yang letaknya hanya beberapa kilometer dari kota Seiwun ibukota Hadhramaut Yaman, pada hari Senin tanggal 14 Sya'ban tahun 1309 H / 1890 M, Ayah Sayyid Idrus bernama Sayyid Salim bin Alawi Al Jufri (1253 H/1835 M,-1335 H/1916 M ), dan ibunya bernama Syarifah Nur Al Jufri dari Wajo Sengkang, Sulawesi Selatan yang mempunyai asal keturunan Bugis, yang ada hubungan kekeluargaan dengan Arung Matoa, Raja Wajo Sengkang. Sayyid Idrus bin Salim Al Jufri merupakan pertautan antara kedua sosok ulama besar (Arab-Bugis), sehingga tidaklah berlebihan jika beliau di kategorikan memilki sosok dan kepribadian yang berbeda dengan ulama lainnya. Beliau adalah putra keempat dari enam bersaudara, yang sesuanya sebagai berikut ${ }^{11}: 1$. Sayyid Abdul Kadir, wafat di Cianjur, Jawa Barat 2. Sayyid Syekh, wafat di Solo, Jawa Tengah 3. Sayyid Alawi, wafat di Hadramaut (Yaman) 4. Sayyid Idrus, (Guru Tua), wafat di Palu Sulawesi Tengah 5. Sayyid Abu Bakar, wafat di Solo, Jawa Tengah 6. Syarifah Lu'lu, wafat di Hadramaut (Yaman).

Sayyid Idrus bin Salim Al Jufri wafat pada hari Senin 12 Syawal 1389 H atau bertepatan dengan 22 Desember 1969, pada jam 02.40 WITA diatas pangkuan Abdul Wahab Abd Muhaimin. ${ }^{12}$

\section{Biografi Singkat Mazhab Syafi'i}

10 Huzaimah T. Yanggo, et. All.. Sayid Idrus Bin Salim Al Jufri Pendiri Alkhairaat Dan Kontribusinya Dalam Pembinaan Umat, ed.,: Abdul Wahab Abd.Muhaimin (Palu dan Jakarta : Yayasan Alkhairaat dan Gaung Persada (GP) Press), 2.

11 Noor Sulaiman Pettalongi Sayyid Idrus Bin Salim Al-Jufri “Guru Tua" Moderenisasi Pendidikan Dan Dakwah Di Tanah Kaili (1930-1969),(yogyakarta:idea press,2005), 19-21.

12 Huzaimah T. Yanggo, et. All.. Sayid Idrus Bin Salim Al Jufri Pendiri Alkhairaat Dan Kontribusinya Dalam Pembinaan Umat, ed.,: Abdul Wahab Abd.Muhaimin (Palu dan Jakarta : Yayasan Alkhairaat dan Gaung Persada (GP) Press), 12. 
Pendiri dari Mazhab Syafi'I yaitu Muhammad bin Idris bin Abbas bin Ustman bin Syafi' bin Sa'ib bin Ubaid bin Abdi Yazid bin Hasyim bin Abdil Muttalib bin Abdi Manaf Al-Quraisyi (berkebangsaan Quraisy), nasab beliau bertemu dengan Rasulullah Saw.pada kakek beliau Abdu Manaf. Beliau di lahir di Gazza Palestina pada tahun $150 \mathrm{H}$ dan beliau wafat pada $204 \mathrm{H}$ di Mesir. ${ }^{13}$

Imam Syafi'I menghasilkan beberapa karya dan beberapa karangan kitab tersebut terbagi dua yaitu kitab Qadim (kitab lama) dan kitab Jadid (kitab baru). Kitab Qadim ialah kitab yang beliau karang sendiri dan di karang oleh sahabatsahabat beliau atas suruhan, ketika berada di Iraq (Bagdad). Adapun kitab Qadim yang terkenal adalah kitab "Al-Hujjah" kitab yang dirumuskan (diriwayatkan) oleh murid beliau antara lain Abu Tsur Ibrahim bin Khalid al Kalbi, Abu 'Ali Hasan bin Muhammad as Za'farani, Abu ‘Ali al Karabisi, dan Imam Ahmad bin Hambal (belum menjadi Mujtahid). Sedangkan Kitab Jadid adalah kitab yang beliau karang sendiri dan di karang oleh murid-muridnya atasa suruhan ketika berada/tinggal di Mesir, Kitab yang terkenal adalah Al Umm yang dirumuskan murid-murid beliau antara lain Abu Ya'qub al Buwaithi, Al Muzzani, Rabi' bin Sulaiman al Jaziri, Rabi' bin Sulaiman al Muradi dan lainlain. ${ }^{14}$

Imam Syafi'I selain menghasilkan beberapa karya kitab Fikih juga menghasilkan beberapa kitab cabang ilmu lain di antaranya yaitu Ar Risalah (kitab ushul fikih pertama di dunia), Risalah fi Bayanin Nasikh al Mansukh (kitab ushul fikih), Ibtalul Istishan (Ushul Fikih), Alqiyas(ushul fikih), Ahkamul Qur'an(ayat-ayat hukum dalam al-Qur'an),Ikhtilaful Ahadis (hadis),Al Musnad(hadits) dan kitabul Asma wal Qabail(sejarah). ${ }^{15}$

${ }^{13}$ Abdul Aziz Asy Syinawi, Al-Aimah Al-Arba'ah: Hayatuhum Mawaqifuhum Ara'ahum, terj. Abdul Majid, Arif Mahmudi, Abbas Sungkar, dan Umar Mujtahid. Biografi empat Imam Mazhab (Jakarta: Beirut publishing, 2016), 385-386

${ }^{14}$ Siradjuddin Abbas Ulama Syafi'I Dan Kitab-Kitabmya Dari Abad Ke abad (Jakarta: Pustaka Tarbiyah, 2011), 32-33.

15 Ibid 32-33. 
Penyebaran mazhab Syafi'l di Indonesia perkembang bersama masuknya Islam di Indonesia. Sala satu ulama yang berjasa dalam menyebarluaskan mazhab Syafi;l adalah Syekh Nuruddin Muhammad Jailani bin Ali bin Hasanji bin Muhammad ar Raniri atau yang di kenal ar Raniri, ia berasal dari ranir nama sebuah Desa di teluk Kambai (Gujarat), India. Pada Tahun 1047 H Ar Raniri berkesempatan datang ke Aceh, ketika itu Aceh dipimpin oleh Sultan Iskandar Tsani (bermazhab Syafi'i) mengangkat beliau menjadi mufti dalam Mazhab Syafi'I (1636-1641 M). sala satu kitab fikih Mazhab Syafi'i karangan beliau adalah Kitab Shiratul Mustaqim merupakan kitab fiqih dalam bahasa Melayu tertua di Indonesia. ${ }^{16}$

Perkembangan mazhab Syafi'l di Indonesia setelah Ar Raniri yaitu di lanjutkan oleh murid beliau yaitu Syekh Abdur Rauf bin Ali Al Fanshuri, terkenal dengan nama "Syekh Kuala" berasal dari Fanshur, Singkel-Aceh (Sumatera). Kitab fikih Syafi'l karanganya adalah Mir-aatut Thulab atas permintaan Sri Sultan Tajul'Alam Shafiyatuddin Syah (berkuasa 1641 M-1675M) untuk di amalkan dan di jadikan pedoman oleh rakyat Aceh. ${ }^{17}$

Mazhab Syafi'l berkambang dengan pesat dari masa kemasa diantara ulama yang mempunyai andil besar dalam perkembangan mazhab Syafi'l di Indonesia antara lain Syeikh Muhammad Arsyad Banjar (wafat $1227 \mathrm{H}$ ), kitab fikih Syafi'l karanganya adalah Sabilal Muhtadin. Syekh Nawawi Bantan (wafat 1315 H) di antara kitab fikih Syafi'l adalah Sulamun Najah, Syarah dari kitab Safinatun Najah karangan Haldrami. ${ }^{18}$

Perkembangan Mazhab Syafi'I di Sulawesi sendiri dibawah oleh para Mubaligh-mubaligh dari Tanah Minangkabau, yang Ketika itu kesultanan Aceh yang di pimpin oleh Sultan Mansyur Syah I. Kesultanan Aceh menjadikan Tanah Minangkabau sebagai bagian dari wilayah mereka sekaligus sebagi tempat

${ }^{16}$ Siradjuddin Abbas, Ulama Syafi'ı Dan Kitab-Kitabmya Dari Abad Ke Abad (Jakarta: Pustaka Tarbiyah, 2011), 331.

17 Ibid 341.

18 Ibid 367-391 
penyebaran Agama Islam, setalah penyebaran agama Islam melahirkan banyak Mubaligh-mubaligh dari Negeri ini yang di kemudian hari menjadi tokoh-tokoh penyiar Agama Islam di Sulawesi di antaranya yaitu Datuk Sahilan, Datuk ri Bandang, Datuk Patimang dan Datuk Ri Tiro. ${ }^{19}$

Mazhab Syafi'I berkembang di Sulawesi Tengah Khususnya di Kota Palu di mulai dengan masuknya Agama Islam di daerah ini, masuknya Agama Islam melalui beberapa tahap - tahap, yaitu: pertama, Agama Islam dari Ternate masuk melalui Gorontalo dan tiba di Lambunu bagian Pantai Teluk Tomini, kedua dibawah oleh Abdullah Raqie ( Dato Karamah) yang di lanjutkan oleh orang - orang Bugis dan Mandar dan ketiga Agama Islam di kembangkan atau di lanjutkan Orang Arab yang berasal dari Hadramaut, Yaman di antaranya Sayyid Idrus bin Salim AlJufri. ${ }^{20}$

3. Upaya Perhimpunan Alkhairaat dalam memperkuat Mazhab Syafi'l di Kota Palu

Perhimpunan Alkhairat dalam Memperkuat Mazhab Syafi'i Di Kota Palu di mulai saatnya berdirihnya Lembaga ini, Lembaga ini di dirihkan oleh Ulama yang berasal dari Hadramaut, Yaman yang di mana akar tradisi di Negeri ini sangat berpegang teguh pada Mazhab Syafi'i. Mazhab Syafi'l menjadi cikal bakal di anut masyarakatnya yakni dari kakek buyut mereka yaitu al Imam al Muhajir yang berhijrah dari Bashrah, Irak ke Hadramaut, Yaman beliau menyebarkan Mazhab Syafi'l kepada Masyarakat Luas, walaupun kapasitas beliau setara dengan para Mujtahid, namun beliau tidak menciptakan Mazhab baru dan menjadikan Mazhab Syafi'ilah sebagai Mazhab yang di anut beliau. ${ }^{21}$

Sayyid Idrus bin Salim Aljufri dengan Lembaga yang beliau dirihkan yaitu Alkhairaat dalam pembinaan hukum Islam di Ilhami dan di warnai oleh

${ }^{19}$ Siradjuddin Abbas, Sejarah \& Keagungan Mazhab Syafi'l (Jakarta: Pustaka Tarbiyah, 2010), .331

${ }^{20}$ Haliadi Sadi dan Syamsuri, Sejarah Islam Di Lembah Palu (Yogyakarta: Q Media, 2016), 7

${ }^{21}$ Ahmad Haydar Baharun, Madzhab Para Habaib \& Akar Tradisinya (Malang:Pustaka Basma, 2013), 73 - 74. 
corak pemikiran Imam Syafi'I tampa menafikan pendapat dan pemikiran Imam - imam Mazhab lainnya, kendati demikian, pemikiran Mazhab Syafi'i lah yang paling dominan di berikan dan di ajarkan kepada Masyarakat. Adapun yang menjadi latar belakang Sayyid Idrus bin Salim Aljufri mengaju pada Mazhab Syafi'l yaitu karena secara teologis beliau menganut Mazhab Syafi'l dan berhaluan ahlu sunnah wal jamaah dan secara kultural masyarakat Islam di Indonesia bermazhab Syafi'l dapat memudahkan beliau dalam memberikan pembinaan hukum Islam. ${ }^{22}$

Penguatan Mazhab Syafi'l sendiri yang di lakukan oleh Perhimpunan Alkhairaat salah satunya dengan menggunakan Buku/Kitab fikih Syafi'i, Habib Ali bin Muhammad AlJufri mengtakan.

Penguatan Mazhab Syafi'i dilakukan di Alkhairaat dengan menggunakan kitab-kitab yang di tulis Ulama-ulama Syafi'l bahkan di setiap kegiatan berpedoman pada Mazhab Syafi'i seperti di dalam mejelis-mejelis ta'lim atau terhadap pembinaan umat islam. ${ }^{23}$

Penguatan Mazhab Syafi'i sebagaimana juga di katakana Ustad Mansur A. Baba

Tariqah Alkhairaat menggunakan Mazhab Syafi'i sebagimana tercantum dalam Anggaran Rumah Tangga (AD/ART) Alkhairaat selain itu, beliau menambahkan dalam hal ibadah Alkhairaat terus konsisten dengan perpedoman dengan Mazhab Syafi'i contohnya Alkhairaat dalam Masalah Rakaat Sholat tarawih menggunakan 20 rakaat kemudian juga, mengenai Azan Sholat Jum'at, Mazhab Syafi'i menggunakan 2 kali azan dan pendapat ini juga di lakukan oleh masjidmesjid yang di pegang oleh Alkhairaat. ${ }^{24}$

Hal yang sama juga di sampaikan oleh Dr. Lukman S. Tahir mengatakan dan mempertegas bahwa

Alkhairaat dan Mazhab Syafi'i bagaikan dua sisi mata uang yang tidak bisa di pisahkan, kehadiran Alkhairaat di kota Palu secara khusus dan

22 Noor Sulaiman Pettalongi Sayyid Idrus Bin Salim Al-Jufri “Guru Tua" Moderenisasi Pendidikan Dan Dakwah Di Tanah Kaili (1930-1969),(Jakarta:Kultura, 2008), 100 - 101.

23 Habib Ali bin Muhammad Aljufri. Ketua Umum Pengurus Besar (PB) Alkhairaat, wawancara oleh penulis di Palu, 16 April 2021.

${ }^{24}$ Ustad Mansur A. Baba. Dewan Ulama Alkhairaat/Pengawas Pendidkan Agama mejelis Pendidikan, wawancara oleh penulis di Palu, 23 November 2020 
Indonesia Timur secara umum, di mana ada madrasah Alkhairaat maka di situ pun mazhab Syafi'i berkembang dengan pesat, selain itu menurut beliau kekuatan dan pengaruh Mazhab Syafi'i di kota Palu begitu kuat karena adanya madrasah yang di bangun oleh Alkhairaat dan selain itu di perkuat oleh dakwah-dakwah yang disampaikan oleh murid-murid dari Alkhairaat. ${ }^{25}$

Penguatan Mazhab Syafi'i sendiri menurut Habib Idrus bin Ali Al Habsyi yang sekaligus merupakan cucu dari dari pendiri Perhimpunan Alkhairaat mengatakan

Penguatan mazhab Syafi'i sendiri di lakukakn oleh guru tua berdasarkan sanad yang keilmuan yang beliau bawah dari Hadramut, Yaman selain itu kata beliau, Mazhab Syafi'i di kembangkan tokohtokoh atau ulama-ulama di kota Palu dalam berdakwah adalah mazhab Syafi'i. ${ }^{26}$

Selain itu penguatan yang di lakukan oleh Habib Idrus bin Ali Alhabsyi terhadap Mazhab Syafi'i dilakukan dengan beberapa cara yaitu membentuk atau mendirihkan pondok pesantren tradisional (salafiyyah) yang mengajarkan ilmu agama dari Bahasa Arab, kemudian penggunaan kitab-kitab fikih yang di karang oleh Ulama-ulama Syafi'i di antaranya kitab Al-Dhakhirah alMusharrafah karangan Sayyid Umar bin Hafiz, Safinat al-Najah karangan oleh Shaykh Salim bin Abdullah bin Sumayr al Hadrami, Nayl al-Raja dan Al-Yaqut alNafis karangan Sayyid Ahmad bin Umar al Shatiri dan kitab Bushra al-Karim bi Sharh Masail al Ta'lim Karangan Sa'id ibn Muhammad Ali Ba'Ashin, serta Hashiyat Al Bujuri karangan Shaykh Burhan al-Din Ibrahim Al Bajuri. Kemudian perluasan cabang-cabang pondok pesantren di antaranya di Desa Kayunyole dan Dataran Tinggi Bulan di Kabupaten Tojo Una-una. ${ }^{27}$

Alkhairaat menurut Ustad Drs. Muh. Nur Aba, M.Hi masyarakat sekaligus Imam Mesjid Nur BTN Palupi mengatakan.

${ }^{25}$ Lukman S. Thahir. Dewan Pakar Alkhairaat/Mantan Sekjen Alkhairaat, wawancara penulis di Palu, 03 Mei 2021.

${ }^{26}$ Habib Idrus bin Ali Alhabsyi. Ketua Pengurus Besar (P.B) Alkhairaat wawancara oleh penulis di Palu, 30 Mei 2021.

${ }^{27}$ Rusli, "Sayyid Idrus bin Ali Alhabsyi,Raudhatul Musthafa, dan Penguatan Mazhab Syafi'i" Http://www.bangrusli.id di akses pada Selasa 08 Juni 2021 pukul 08.55 
Pendidikan dan dakwah Alkhairaat tidak terlepas dari mazhab Syafi'i sehingga sehingga sangat kental dengan mazhab Syafi'i terkhusus dalam masalah-masalah ibadah. ${ }^{28}$

\section{Ustad Drs. Salim D. Masuka Lc., M.HI mengatakan}

Alkhairaat dinyatakan dalam AD/ART bermazhab Syafi'l selain itu dalam Pendidikan tentang hukum Islam menggunkan buku-buku yang di karang oleh ulama-ulama Syafi'i yang menjadi pegangan, selain itu dalam hal beribadatan juga menggunakan mazhab Syafi,i serta dalam dakwah setiap penyampain nya tidak terlepas dari mazhab Syafi'i, sebagaimana yang telah di ajarkan guru-guru Alkhairaat terdahulu dalam pembinaan masayakat. ${ }^{29}$

Dr. Haerullah Muh. Arief M.HI Mengatakan

Penguatan mazhab Syafi'I dilakukan oleh Lembaga Pendidikan Islam Alkhiaraat adalah satu kesatuan, bentuk pengutan yang di lakukan adalah dengan mendirikan madrasah-madrasah hingga perguruaan tinggi sebagai bentuk konsistensi penguatan mazhab Syafi'l, selain itu beliu juga mengatakan bahwa penguatan Mazhab Syafi'l terus di lakukan melalui pondasi dalam hal ini madrsah diniyyah dalam hal pendikan dalam dakwah sendiri juga dengan mejelis-mejelis ta'lim yang di kelolah lansung oleh Alkhairaat maupun ustad-ustad atau guruguru dari Alkhairaat. ${ }^{30}$

Penguatan Mazhab Syafi'i yang di lakukan oleh Lembaga Pendidikan Islam Alkhairaat, dalam bentuk Pendidikan adalah dengan mendirikan madrasah-madrasah dari tingkat Pendidikan Anak Usia Dini (PAUD) hingga perguruaan tinggi. Madrasah adalah pondasi awal dalam membentuk doktrindoktrin keagamaan termasuk dalam bermazhab, selain itu dalam pembinaan hukum Islam juga dalam hal ini mejelis-mejelis ta'lim Perhimpunan Alkhairaat juga mengambil peran penting dalam hal ini masyarakat yang tidak sempat mengenyam Pendidikan di Perhimpunan Islam Alkhairaat untuk penguatan ibadah atau dalam menjalankan syariat Islam.

\footnotetext{
${ }^{28}$ K.H. Muh. Nur Aba. Mantan ketua Ikatan Alumni Alkhairaat (IKAAL)/Imam Mesjid Nur BTN Palupi Permai wawancara oleh penulis, tanggal 19 Maret 2021

29 Drs. Salim D. Masuka Lc.,M.HI. ketua Mejelis Pendidikan Alkhairaat/Masyarakat Kelurahan Birobuli Utara, Palu Selatan wawancara penulis, tanggal 06 Mei 2021.

${ }^{30}$ Haerullah Muh. Arief wakil sekretaris Ikatan Alumni Alkhairaat (IKAAL)/kepala Kantor Urusan Agama (KUA) Palu Barat. Wawancara 29 April 2021.
} 
4. Hambatan Terhadap Perhimpunan Alkhairaat Dalam Memperkuat Mazhab Syafi'i Di Kota Palu

Perkembangan setiap organisasi tidak terlepas dari berbagai hambatan baik itu bersifat dari dalam atau internal organisasi itu sendiri maupun faktor dari luar atau eksternal organisasi, begitupun Lembaga Pendidikan Islam Alkhairaat sendiri. Dalam perkembangan atau memperkuat mazhab Syafi'i sendiri Perhimpunan Alkhairaat di Kota Palu terdapat hambatan-hambatan.

Hambatan yang di hadapi oleh Perhimpunan Alkhairaat tersebut dalam penguatan mazhab Syafi'I di Kota Palu tidak terlalu berarti, di sebabkan mazhab yang di anut oleh masyarakat Palu adalah mazhab Syafi'i.

Hambatan yang di hadapi Perhimpunan Alkhairaat adalah menurut Dr. Lukman S. Tahir.

Hambatan yang dihadapi berupa adalah madrasah-mdrsah itu sendiri yang bersifat fasilitas yang mereka miliki untuk menunjang Pendidikan itu sendiri. ${ }^{31}$

Menurut Habib Idrus bin Ali Alhabsyi hambatan yang dihadapi

Berkurangnya ulama-ulama atau kader-kader Alkhairaat yang terjun lansung dalam pembinaan umat sebagaimana di masa Sayyid Idrus, ditambah makin besarnya Lembaga Alkhairaat sehingga untuk mengcover atau memback-up sekolah-sekolah di pelosok-pelosok tak terpenuhi selain itu banyak perubahan-perubahn mendasar dalam pola Pendidikan, beliau memberi contoh porsi jam mata pelajaran tertentu, dalam hal ini adalah Pendidikan agama yang menggunakan akan tetapi porsi mata pelajaran umum di tambah lagi, mata pelajaran yang menggunakan berbahasa Arab telah di kurangi. ${ }^{32}$

Adapun menurut Ustad Drs. Salim D. Masuka Lc.,M.HI

Hambatan bersifat teknisi yang berhubungan dengan madrasahmadrasah dalam hal ini sarana-sarana, pendanaan serta metode pengembangannya agak lambat yang berdampak pada pengembangan madrasah-madrasah sehingga berdampak pula pada pembinaan umat. ${ }^{33}$

${ }^{31}$ Lukman S. Thahir. Dewan Pakar Alkhairaat/Mantan Sekjen Alkhairaat, wawancara penulis di Palu, 03 Mei 2021.

32 Habib Idrus bin Ali Alhabsyi. Ketua Pengurus Besar (P.B) Alkhairaat wawancara oleh penulis di Palu, 30 Mei 2021.

${ }^{33}$ Salim D. Masuka ketua Mejelis Pendidikan Alkhairaat/Masyarakat Kelurahan Birobuli Utara, Palu Selatan wawancara penulis, tanggal 06 Mei 2021. 
Selain itu menurut Dr. Haerullah M. Arief S.Ag.,M.HI

Hambatan yang di alami berupa perkembangan zaman itu sendiri, banyak pola dan perubahan yang terjadi di masyarakat di antaranya bermunculan sekolah-sekolah yang bukan berbasis agama atau sekolahsekolah umum serta lahirnya madrasah-madrasah islami yang di dirikan organisasiorganisai keagamaan yang berdasarkan pemahaman dan mazhab yang mereka anut. ${ }^{34}$

Hambatan yang di hadapi oleh Perhimpunan Alkhairaat, sendiri berupa sarana-sarana penunjang dari Madrasah-madrasah yang di dirihkan oleh Perhimpunan Alkhairaat itu sendiri, selain itu dengan meluasanya dan besarnya Alkhairaat menjadikan pembinaan hukum islam semakin berat karena di sebabkan kurangnya tenaga pendidik dan mubaligh untuk mengcover seluruh cabang-cabang Alkhairaat. Dengan bermunculannya sekolah-sekolah yang bukan berlandaskan agama juga menjadi salah satu hambatan terhadap penguatan mazhab Syafi'i serta banyak madrasahmadrsah yang didirihkan oleh Lembaga yang berdasarkan pemahaman dan mazhab mereka.

\section{KESIMPULAN}

Berdasarkan hasil penelitian dan pembahasan yang telah di deskripsikan pada bab sebelumnya maka penulis dapat mengambil kesimpulan sebagai berikut:

1. Upaya Peran Perhimpunan Alkhairaat memperkuat mazhab Syafi'i di Kota Palu sangat besar, melalui Pendidikan dan dakwah . melalui pendidikan Lembaga Pendidikan Islam Alkhairaat mengembangkan madrasah-madrasahnya, bisa di bilang dimana berada madrasah Alkhairaat maka di situlah mazhab Syafi'i menjadi mazhab yang di anut oleh masyarakatnya. Selain itu didalam sistem Pendidikan, Perhimpunan Alkhairaat, banyak menggunakan kitab-kitab yang di karang atau ditulis oleh Ulamaulama yang bermazhab Syafi'l di tambah sang pendiri Perhimpunan Alkhairaat yaitu Sayyid Idrus bin Salim Al Jufri adalah

\footnotetext{
${ }^{34}$ Haerullah Muh. Arief wakil sekretaris Ikatan Alumni Alkhairaat (IKAAL)/kepala Kantor Urusan Agama (KUA) Palu Barat. Wawancara 29 April 2021.
} 
ulama yang berasal dari Negeri Hadramaut Yaman, di mana Negeri ini, yang memegang akar tradisi dan peribadatannya menggunakan Mazhab Syafi'l. selain itu dalam hal dakwah sendiri ulama-ulama atau murid-murid yang berasal dari Alkhairaat banyak menyampaikan dakwahnya menggunakan mazhab Syafi'i atau mengutip dari pendapat-pendapat Ulama-Ulama Mazhab Syafi'I terhadap pembinaan hukum Islam di tengah masyarakat termasuk Di dalam mejelis-mejelis ta'lim yang di bawahi lansung oleh Perhimpunan Alkhairaat ataupun oleh Ulama-ulama yang berasal dari Alkhairaat.

2. Hambatan yang di hadapi oleh Perhimpunan Alkhairaat sendiri dalam memperkuat Mazhab Syafi'i di Kota Palu berupa fasilitasfasilitas yang kurang memadai dari Madrasah-madrasah sendiri sehingga mengakibatkan lambatnya perkembangan Pendidikan tersebut, selain itu dengan semakin luasnya dan besarnya Perhimpunan Alkhairaat, tak mampu di cover oleh seluruh ulamaulama atau pendidik dari Alkhairaat itu sendiri ditambah lagi dengan semakin berkurangnya ulama atau murid dari Alkhairaat yang terjun lansung ke masyrakat dalam pembinaan terhadap umat islam serta semakin banyaknya tumbuh dan berkembang sekolahsekolah yang bukan berbasis Agama atau yang bersifat umum serta Lembaga-lembaga yang mendirihkan madrasah berdasarkan pemahaman dan mazhab yang mereka anut 


\section{Referensi}

Abbas Siradjuddin, Ulama Syafi'I Dan Kitab-Kitabmya Dari Abad Ke abad (Jakarta: Pustaka Tarbiyah, 2011)

Abbas Siradjuddin, Sejarah \& Keagungan Mazhab Syafi'l (Jakarta: Pustaka Tarbiyah, 2010)

Abdun Abdullah, Sekelumit Tentang Perguruan Alkhairaat Dan Pendirinya, (malang: Daruttauhid 1996)

Asy Syinawi Abdul Aziz, Al-Aimah Al-Arba'ah: Hayatuhum Mawaqifuhum Ara'ahum, terj.

Abdul Majid, Arif Mahmudi, Abbas Sungkar, dan Umar Mujtahid. Biografi empat Imam Mazhab (Jakarta: Beirut publishing, 2016)

Bachmid Ahmad, Sang Bintang Dari Timur Sayyid Idrus Al-Jufri Sosok Ulama \& Sastrawan,( Jakarta: studia press, 2007)

Baharun Ahmad Haydar, Madzhab Para Habaib \& Akar Tradisinya (Malang:Pustaka Basma, 2013)

Pettalongi Noor Sulaiman, Sayyid Idrus Bin Salim Al-Jufri "Guru Tua" Moderenisasi Pendidikan Dan Dakwah Di Tanah Kaili (1930-1969),(yogyakarta:idea press,2005)

Rusli, "Sayyid Idrus bin Ali Alhabsyi,Raudhatul Musthafa, dan Penguatan Mazhab Syafi'i" Http://www.bangrusli.id di akses pada Selasa 08 Juni 2021 pukul 08.55

Sadi Haliadi dan Syamsuri, Sejarah Islam Di Lembah Palu (Yogyakarta: Q Media, 2016)

T. Yanggo Huzaimah, et. All.. Sayid Idrus Bin Salim Al Jufri Pendiri Alkhairaat Dan Kontribusinya Dalam Pembinaan Umat, ed.,: Abdul Wahab Abd.Muhaimin (Palu dan Jakarta : Yayasan Alkhairaat dan Gaung Persada (GP) Press)

\section{* Mahasiswa dan dosen fakultas syariah IAIN Palu}

